Rapp. Grønlands geol. Unders. 88, 51-54 (1979)

\title{
SILURIAN CARBONATE MOUNDS IN PEARY LAND, NORTH GREENLAND
}

Philip D. Lane and Alan T. Thomas

Carbonate mounds are important features in the Silurian of North Greenland. They occur in an approximately west-east trending belt from Washington Land in the west to the Victoria Fjord area in the east - a distance of some $300 \mathrm{~km}$ (Dawes, 1971, 1976). Mounds in Peary Land, $250 \mathrm{~km}$ to the east of the Victoria Fjord area, are much less common than in western North Greenland. They are, as yet, not known in extreme eastern Peary Land or in Kronprins Christian Land (Christie \& Peel, 1977).

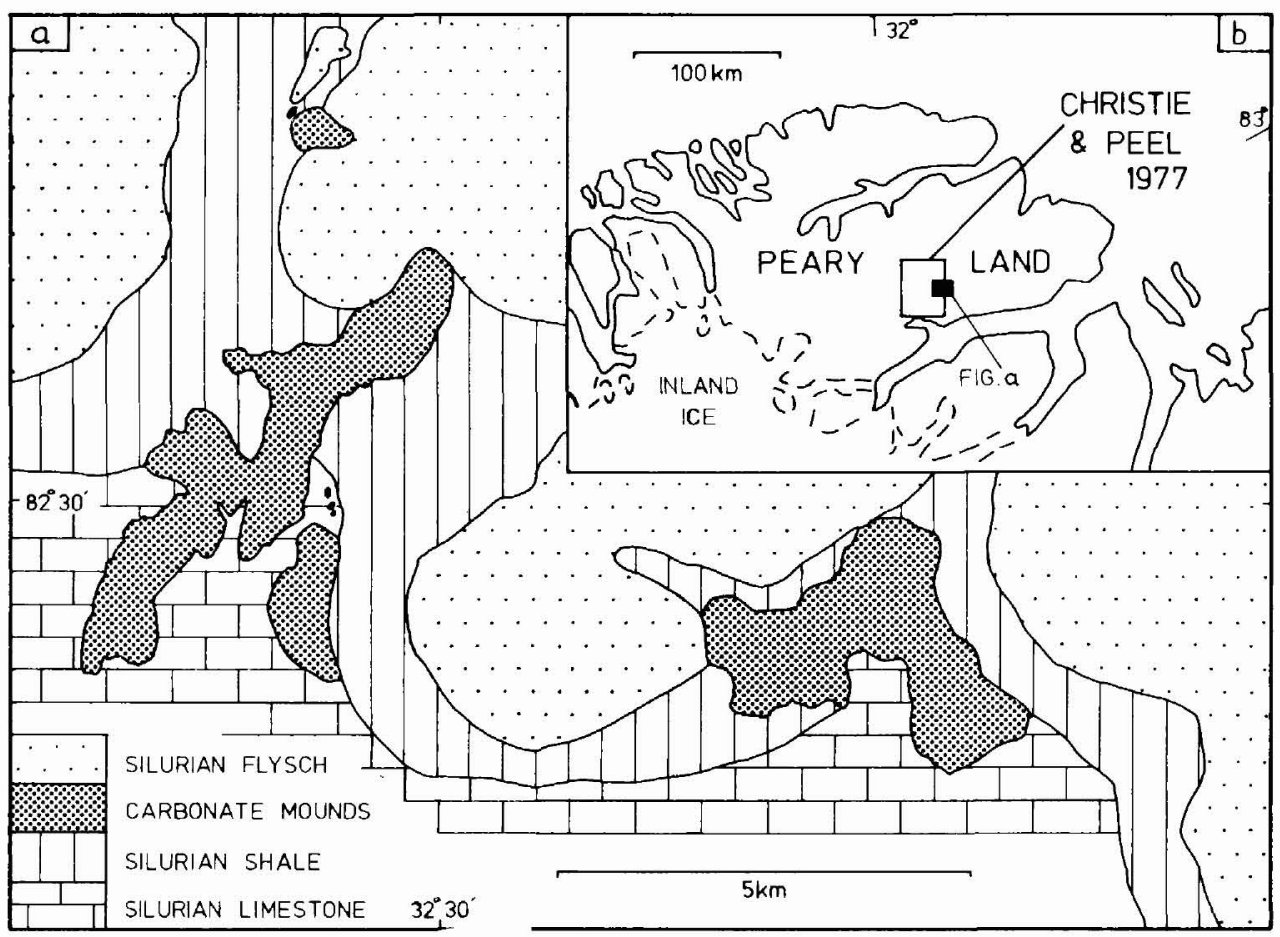

Fig. 14. Relationship between carbonate mounds and other Silurian formations in central Peary Land. The inset shows the location of the mapped area relative to fig. 4 of Christie \& Peel (1977). 


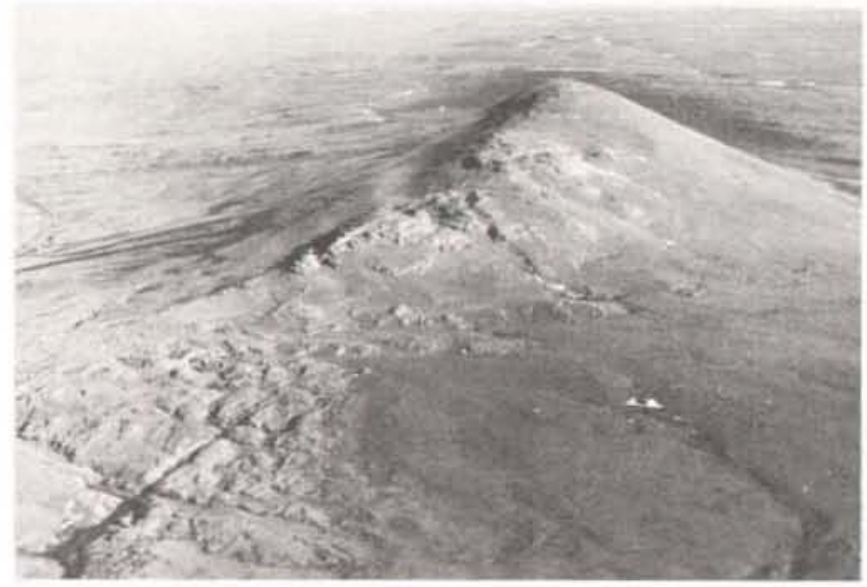

Fig. 15. General view looking NNE of the carbonate mound discussed. The stem of the inverted Y-shaped mound forms the main feature. Behind the mound, the dark Silurian shale formation and well bedded Silurian flysch formation crop out. The photograph, taken looking approximately down the regional dip, shows the banking up against and eventual covering of the mound by the flysch formation.

We spent part of the 1978 field season on an examination of carbonate mound structures in central Peary Land. Most time was devoted to the group of mounds (figs. 14, 15) previously discussed by Mayr (1976) and Christie \& Peel (1977); detailed mapping and collecting were undertaken. Only a brief visit was made to the eastern mound shown in fig. 14, and the outcrop shown is based on a photointerpretation. We also visited four structures, which from photointerpretation appeared to be carbonate mounds, in an area $55 \mathrm{~km}$ to the west of those described here. One was found to be a moraine, and the others to be composed of limestones of the un-named Silurian limestone formation of Christie \& Peel (1977) which had been locally faulted and tilted into apparent domal structures. About 15 other structures which could be carbonate mounds, varying in size from $200 \mathrm{~m}$ to $3 \mathrm{~km}$ in maximum dimension, occur in eastern Peary Land up to $35 \mathrm{~km}$ east of those described here. It was only possible to examine two of these but both were found to be composed of limestones of the un-named Silurian limestone formation. Discussion below is restricted to the westerly group of mounds shown in fig. 14.

In detail, the distinction of carbonate mounds from bedded limestone of the un-named Silurian limestone formation in which they are founded can be difficult. The dominant mound lithofacies consists of white to light grey crinoidal and stromatoporoidal bioclastic limestone. Bedding varies from massive in the core rocks to highly variable in sequences of talus wedges in the outer parts of the mounds. Depositional dips radiate out from the main core, and from local cores of massive limestones of much smaller size, particularly in the lower levels of the mounds. The mound talus lithofacies are similar to some of those developed in the un-named Silurian limestone formation. In mapping the extent of the mounds, their lithofacies were found to be generally lighter in colour (particularly on fresh surfaces) than those of the un-named Silurian limestone formation, and to lack silicification of the fossils a phenomenon characteristic of that formation. In the group of mounds studied, the lowest limestone referred to the mounds (occurring at the southern tip of the south-west arm of the inverted $\mathrm{Y}$-shaped outcrop) directly overlies beds referable to member $\mathrm{E}$ of the un-named Silurian limestone formation (Christie \& Peel, 1977). Massive, grey, regularly bedded limestones with silicified fossils below give way to pale, irregularly bedded limestones above containing calcitic fossils. These latter limestones are raised into mounds of small amplitude 
and commonly show structures resembling mud cracks. These limestones, as higher levels of the mound are examined, exhibit larger and larger local mound structures (fig. 16) in which mud cracks were not recorded. At higher levels still, these local mounds fuse to form a unified structure with a large massively bedded core, whose radial dips indicate a structure a few kilometers in maximum dimension.

Farther to the north of the area the relationship between the mounds and the other Silurian formations can be studied in a series of sections. At a point just south of where the arms of the inverted $\mathrm{Y}$-shape meet, variably bedded mound talus material interdigitates with limestone belonging to member $\mathrm{E}$ of the un-named Silurian limestone formation. In this section, about $50 \mathrm{~m}$ of mound limestone occurs below beds belonging to the un-named Silurian limestone formation. Farther north the mound is progressively overlapped by the Silurian shale and Silurian flysch formation (fig. 14). Residual patches of the Silurian shale formation occur on the western side of the stem of the inverted Y-shape and these contain thin beds of dark crinoidal limestone. These limestone beds may be derived from the mound and perhaps indicate that mound erosion was taking place while the shale was being deposited. The depositional dips seen in the mound, and the pattern of progressive overlap by younger formations, indicate that the mounds were significant positive features on the sea floor.

Fossils are abundant throughout the mounds with stromatoporoidal and crinoidal debris overwhelmingly dominant. Pockets of other fossils occur and include brachiopods, rugose and tabulate corals, trilobites, gastropods, cephalopods, rostroconchs and bivalves. The smallest mound at the extreme northern end of the group, yielded the trilobites Encrinurus, Calymene, Platylichas, Meroperix, cf. Cheirurus, a tropidocoryphine, and new genera of scutelluids and proetids. The main mound yielded many large Meroperix and cf. Cheirurus, together with Cheirurus cf. C. centralis, Stenopareia cf. S. somnifer, Youngia, Calymene, Scharyia, Encrinurus, proetids, effaced scutelluids and lichids. The Meroperix and Stenopareia species may indicate upper Llandovery while $C$. cf. $C$. centralis suggests continuation of mound sedimentation into the Wenlock (possibly late Wenlock). Graptolites collected from the residual outcrops of Silurian shale formation mentioned above include a large and diverse fauna of cyrtograptids (Cyrtograptus canadensis?), straight, curved and rastritiform monograptids and retiolitids (Stomatograptus), possibly indicating a low Wen-

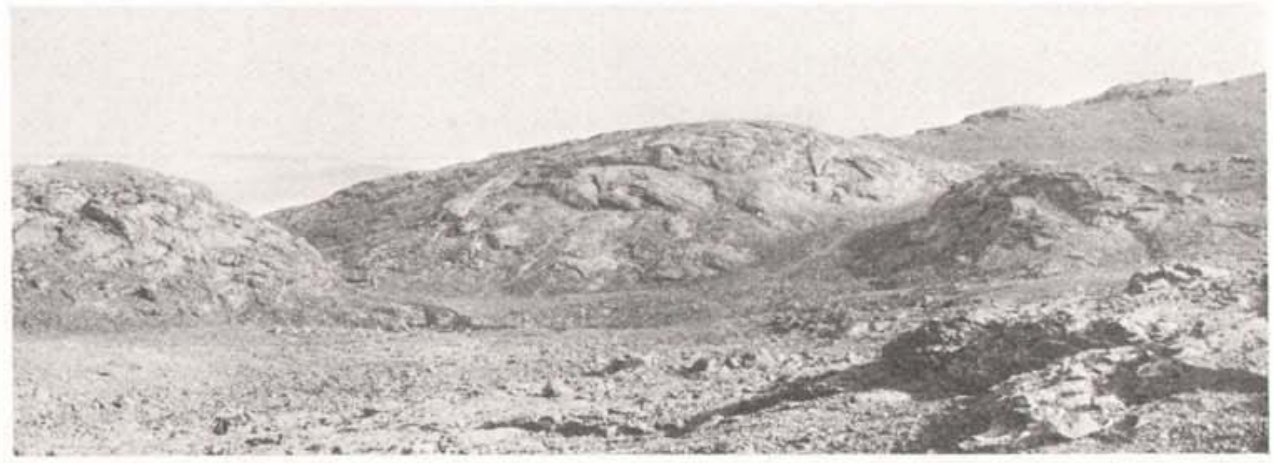

Fig. 16. Larger amplitude mounds showing radial dips of talus wedges. Locality at southern part of stem of Y-shaped mound (left middle foreground of fig. 15). Largest mound is c. $100 \mathrm{~m}$ in diameter. 
lock age. Mayr (1976) considered the coral-brachiopod fauna of the mounds to indicate a Wenlock to lower Ludlow age while Christie \& Peel (1977) cited more detailed faunal evidence indicative of the late Llandovery to Wenlock. Initiation of mound growth was certainly during the deposition of member $\mathrm{E}$ of the un-named Silurian limestone formation (of late Llandovery age), and may have continued through much of the Wenlock.

It is hoped that microfossil determinations will allow a better understanding of the history and evolution of this group of carbonate mounds. Samples for micropalaeontological processing were collected throughout sections in the area; from the bedded limestones of member $E$ of the un-named Silurian limestone formation both beneath the mound and wherever found flanking the mound, from predominantly massively bedded mound core (including one almost complety exposed and continuous section of $300 \mathrm{~m}$ ), from talus wedges and from the thick dark limestones interbedded with the graptolitic laminated mudstones in the erosional remnants described above. Additionally, most macrofosssil collections of necessity were made from loose blocks (many of large size, which we regarded as 'float'). Micropalaeontological samples routinely taken from these blocks should aid more precise determination of the age of these faunas.

\section{References}

Christie, R. L. \& Peel, J. S. 1977: Cambrian-Silurian stratigraphy of Børglum Elv, Peary Land, eastern North Greenland. Rapp. Gronlands geol. Unders. 82, 48 pp.

Dawes, P. R. 1971: The North Greenland fold belt and environs. Bull. geol. Soc. Denmark 20, 197-239.

Dawes, P. R. 1976: Precambrian to Tertiary of northern Greenland. In Escher, A. \& Watt, W. S. (edit.) Geology of Greenland, 248-303. Copenhagen: Geol. Surv. Greenland.

Mayr, U. 1976: Middle Silurian reefs in southern Peary Land, North Greenland. Bull. Can. Petrol. Geol. 24, 440-449. 